\title{
Rancang Bangun Sistem Informasi Akademik Sekolah Smp Islam Al-Fatah Dengan Metode Waterfall
}

\author{
1. Rachmat Suryadithia, 2. Muhammad Faisal, 3. Priyono \\ 1. Universitas Bina Sarana Informatika Kampus Kota Bogor \\ e-mail : rachmat.rcs@bsi.ac.id \\ 2. STMIK Nusa Mandiri Jakarta \\ e-mail:muhammad.mal@nusamandiri.ac.id \\ 3. Universitas Bina Sarana Informatika Jakarta \\ e-mail : priyono.pyo@bsi.ac.id
}

\begin{abstract}
ABSTRAKSI - Dengan mengacu pada pelayanan informasi sekolah, SMP Islam Al-Fatah Jakarta mengalami kendala untuk menyampaikan informasi akademik untuk siswa-siswinya, wali murid atau orang tua siswa sulit mengetahui perkembangan belajar anak-anaknya disekolah seperti melihat nilai tugas, nilai UTS, dan Nilai UAS, karena semua metode penyampaian informasi ini masih konvensional. untuk memenuhi kebutuhan guru, siswa, maupun wali murid yang menjadi kendala pada proses terbentuknya sebuah penyampaian informasi akademik sekolah yaitu Konsep yang telah di analisis berdasarkan masalah dan kebutuhan pemakai yang di implikasikan dengan membuat sistem informasi yang terstruktur dan efisien berbasis digital, praktis, user friendly. Pengelola memiliki hak akses untuk mengolah data nilai siswa, input nilai absen, nilai tugas, nilai UTS, dan nilai UAS siswa. Sedangkan siswa maupun wali murid siswa mempunyai hak akses untuk melihat nilai-nilai akademiknya. Sistem informasi akademik sekolah yang dibangun ini berbasis website dengan menggunakan bahasa script PHP, dan database MySql yang akan dijelaskan menggunakan UML ((Unified Modelling Language). sistem informasi sekolah memudahkan para guru, siswa dan orang tua murid dalam informasi kegiatan sekolah serta memberikan laporan mengenai siswa dalam hal-hal akademik selama menjadi bagian dalam siswa sekolah tersebut dan memberikan informasi secara akurat, efisien dan relevan.
\end{abstract}

Kata kunci : website, UML, nilai

ABSTRACT - With reference to the school information service, Al-Fatah Islamic Islamic Middle School Jakarta has difficulties in conveying academic information to its students, parents or parents find it difficult to know the learning progress of their children at school such as seeing the value of assignments, midterm grades, and midterm grades, because all methods of delivering this information are still conventional. to meet the needs of teachers, students, and guardians of students who become obstacles in the process of forming a delivery of school academic information that is the concept that has been analyzed based on the problems and needs of users which is implied by creating a structured and efficient information system based on digital, practical, user friendly. Managers have access rights to process student grade data, input absentee values, assignment grades, UTS scores, and student UAS grades. While students and guardians of students have the right of access to see their academic values. The school's academic information system is built based on a website using the PHP script language, and a MySql database that will be explained using UML ((Unified Modeling Language). The school's information system makes it easy for teachers, students and parents of students to inform school activities and provide reports on students in academic matters as long as they are a part of the school students and provide information accurately, efficiently and relevant.

Keyword : website, UML, grade

\section{PENDAHULUAN}

Pada instansi pendidikan khususnya dalam menghadapi tuntutan perkembangan zaman tidak lepas dari berbagai persoalan yang ada, namun diharapkan mampu memanfaatkan teknologi sebagai solusi dalam pemecahan permasalahan dan hambatan dengan menggunakan suatu sistem pengolahan data untuk memperoleh informasi dan hasil yang diharapkan.

Selama ini, informasi yang ada pada SMP 
Islam Al-Fatah mengenai presensi siswa harian, nilai-nilai ulangan baik harian maupun tengah dan akhir semester, hingga kegiatan-kegiatan di sekolah, sangat sulit untuk didapatkan oleh wali murid karena sistem yang digunakan hanya sebatas pengumpulan informasi dalam bentuk excel dan wali murid mengetahui informasi ketika pengambilan rapot serta pengumuman yang dibuat oleh sekolah. Sehingga tidak ada informasi yang up to date setiap hari dari sekolah kepada wali murid tentang perkembangan nilai siswa di sekolah,informasi tentang presensi siswa di sekolah, dan perilaku di sekolah.

Berdasarkan uraian di atas, maka SMP Islam Al-Fatah memerlukan suatu rancang bangun sistem informasi akademik dengan dukungan Web untuk membantu mengatasi permasalahan mengenai presensi siswa harian, nilai-nilai ulangan baik harian maupun tengah dan akhir semester secara detil, hingga kegiatan-kegiatan di sekolah. Informasi melalui Web ini wali murid dapat mengaksesnya dimanapun dan kapanpun untuk mendapatkan informasi akademik dan perilaku siswa di sekolah.

Dengan adanya sistem informasi akademik yang dibangun dengan teknologi Web ini dapat membantu baik pihak sekolah, siswa, dan wali murid/orang tua siswa untuk berbagi dan meminta informasi-informasi penting tentang siswa dan segala kegiatannya di sekolah. Karena dengan mudah wali murid dapat mengakses informasi nilai, presensi siswa, dan kegiatan di sekolah dengan menggunakan internet yang sudah banyak digunakan masyarakat pada umumnya.

Penyajian informasi akademik yang cepat dan akurat saat ini sangat dibutuhkan oleh banyak instansi, khususnya pada lembaga pendidikan yang terus menerus berkembang sejalan dengan kemajuan tekhnologi yang begitu pesat. Hal ini didukung oleh peneletian sebelumnya yaitu Nataniel dan Dyna (2009:18) menjelaskan bahwa "sistem informasi akademik berbasis web ini merupakan suatu sistem yang sangat penting untuk menunjang kecepatan dan ketepatan dalam penyajian informasi tentang perkembangan pendidikan siswa". Selain itu Perkembangan siswa dapat di awasi secara efisien dan cepat seperti yang di simpulkan oleh Tanti Kristanti dan Niluh Redita A.K (2012:85) "Sistem informasi nilai yang mampu menyampaikan informasi perkembangan belajar siswa kepada siswa - siswi dan kepada guru sendiri yang berbasiskan web sebagai salah satu bentuk penerapan TI di dunia pendidikan". Sistem Informasi sekolah berdasarkan konsep (Input, Processing, Output-IPO) dapat dilihat pada gambar II.1 dibawah ini.

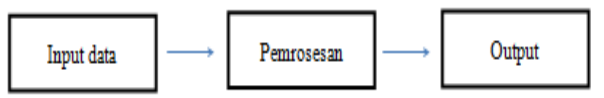

Sumber: Al Fatta(2007:13)

\section{Gambar 1. Konsep Sistem Informasi}

\section{METODE PENELITIAN}

Dalam penyusunan penulisan ini penulis menggunakan metode System Development Life Cycle (SDLC) yang merupakan metodologi umum dalam pengembangan sistem yang menandai kemajuan dari usaha analisa dan desain.

2.1. Teknik Pengumpulan Data

a. Metode Pengamatan Langsung (Observation)

Metode ini merupakan cara pengumpulan data secara langsung dengan mengamati objek penelitian dari sejumlah individu dalam jangka waktu yang bersamaan. Observasi adalah pengamatan langsung suatu kegiatan yang sedang dilakukan. Untuk mendapatkan data yang diperlukan, penulis menggunakan cara pengamatan langsung di SMP Islam Al-Fatah Jakarta.

b. Metode Wawancara (Interview)

Dalam metode ini penulis melakukan suatu kegiatan percakapan yang direncanakan dan bermanfaat untuk mencapai tujuan tertentu, kegiatan ini dilakukan dengan mewawancarai langsung pihak-pihak yang berwenang di SMP Islam Al-Fatah, seperti wawancara kepada Rahmat Zainal,Spd Selaku guru Matematika dan Nina Cahyani Sebagai Tata Usaha.

c. $\quad$ Metode Studi Pustaka (Search in Library)

Dengan metode ini membantu penulis dalam hal pembuatan skripsi yang ditunjang dengan beberapa buku dan literatur yang berkaitan dengan materi yang dibuat dalam penyusunan penelitian ini Pada metode ini penulis mendapat banyak bahan masukan tentang bagaimana merancang atau mengembangkan suatu sistem informasi menurut para ahlinya. Juga pada metode ini penulis membuka, mengambil dan mengutip dari beberapa kutipan para ahli yang berdasarkan dari jurnal ilmiah nasional.

2.2. Konsep Dasar Model Pengembangan Sistem

Menurut McLeod (2008:10) " Sistem informasi adalah suatu sistem virtual yang memungkinkan manajemen mengendalikan operasi sistem fisik perusahaan".

Sistem fisik (physical system) perusahaan terdiri atas sumber-sumber daya berwujud seperti bahan baku, karyawan, mesin dan uang. Sedangkan sistem virtual (virtual system) terdiri atas sumber 
daya informasi yang digunakan untuk mewakili sistem fisik.

Karakteristik sistem yang terdiri dari beberapa karakter yaitu: komponen-komponen, suatu sistem berisi komponen yang saling berinteraksi atau saling bekerja sama menurut Jogiyanto (2005a:54), adalah:

\section{Komponen Sistem}

Suatu sistem terdiri dari sejumlah komponen yang saling berinteraksi, yang artinya saling bekerja sama membentuk satu kesatuan.

2. Batasan Sistem

Batasan sistem atau (boundary) merupakan daerah yang membatasi antara suatu sistem dengan sistem lainnya atau dengan lingkungan luarnya.

3. Lingkungan Luar Sistem

Lingkungan luar (environment) dari suatu sistem adalah apapun diluar batas sistem yang mempengaruhi operasi sistem

4. Penghubung Sistem

Penghubung (interface) merupakan media penghubung antara satu subsistem dengan subsistem yang lainnya.

5. Masukan Sistem

Masukan (input) adalah energi yang dimasukan ke dalam sistem.

6. Keluaran Sistem

Keluaran (output) adalah hasil dari energi yang diolah dan diklasifikasikan menjadi keluaran yang berguna dan sisa pembuangan.

7. Pengolah Sistem

Suatu sistem dapat mempunyai suatu bagian pengolah yang akan merubah masukan menjadi keluaran.

8. Sasaran Sistem

Suatu sistem pasti memiliki tujuan (goal) atau sasaran (objective).

\subsection{System Development Life Cycle (SDLC)}

metode waterfall menurut Sommerville dalam (Sasmito, 2017) menjelaskan bahwa metode waterfall memiliki tahapan utama dari waterfall model yang mencerminkan aktifitas pengembangan dasar. Terdapat 5 (lima) tahapan pada metode waterfall, yaitu requirement analysis and definition, system and software design, implementation and unit testing, integration and system testing, dan operation and maintenance.

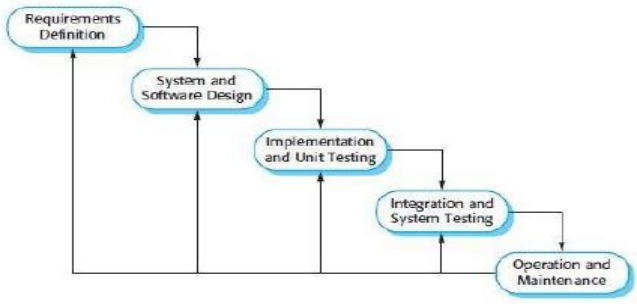

Sumber: (Sasmito, 2017:8)

\section{Gambar 2. Model Waterfall Menurut Sommerville}

\section{Requirements analysis and definition}

Sistem Informasi akademik sekolah pada sekolah SMP Islam Al-Fatah Jakarta ini membutuhkan suatu sistem terkomputerisasi untuk mempermudah proses kegiatan akademik baik pada kegiatan pembelajaran maupun kegitan ekstrakulikulier pada kegiatan sekolah.

2. System and software design

Tahapan perancangan sistem ini dilakukan setelah melakukan analisis kebutuhannya dengan menggunakan suatu tools untuk mempermudah menyusun dan mendisain sistem agar lebih terstruktur, rancangan yang dibuat seperti usecase sistem housekeeping inventory, activity login, dll. Tools program yang digunakan secara umum yaitu ERD, LRS dan UML menggunakan software Microsoft Visio dan Enterprise Architecture.

\section{Implementation and unit testing}

Pada tahap ini, perancangan perangkat lunak direalisasikan sebagai serangkaian program atau unit program yang dibuat dengan menggunakan bahasa php, Web Disegn dan menggunakan database MySQL serta Web Server sebagai tools editornya. Pengujian menggunakan blackbox testing melibatkan verifikasi bahwa setiap unit memenuhi spesifikasinya.

\section{Integration and system testing}

Setiap unit program digabungkan dan diuji menggunakan metode blackbox testing seperti pada tahap sebelumnya, perbedaanya yakni pada tahap ini tidak membutuhkan pengetahuan tentang kode dan logika pemrogramman. Sistem diuji secara menyeluruh sebagai sebuah sistem lengkap untuk memastikan apakah sesuai kebutuhan atau tidak. Setelah pengujian selesai dilakukan, perangkat lunak dapat digunakan oleh sekolah SMP Islam AlFatah Jakarta.

\section{Operation and maintenance}

Tahapan ini merupakan tahapan yang paling panjang. Program dipasang dan digunakan secara nyata. Maintenance melibatkan pembetulan kesalahan yang tidak di temukan pada tahapantahapan sebelumnya, meningkatkan implementasi dari unit sistem, dan meningkatkan layanan sistem sebagai suatu kebutuhan sistem yang baru.
2.4. Penerapan/Implementasi Sistem Implementation)
a. Penulisan Program dan Instalasi 
Merupakan tahap penulisan program yang telah dianalisis dan didesain semua maka program yang digunakan adalah PHP dan database yang digunakan $\mathrm{MySql}$

b. Desain Review

Dalam tahap ini tidak hanya menguji desain yang digunakan namun menguji semua sistem yang telah diterapkan seperti tidak ada lokasi link, image yang salah, pengujian sistem seperti penyimpanan data, update artikel dan lain-lain.

c. Pemilihan Sumber daya Hardware dan Software

Dalam tahap ini software dan hardware digunakan untuk $W e b$ server.

d. Pengujian Web dan Dokumen Web

Menguji Web dengan berbagai teknologi browser yang ada, serta pemeriksaan dokumen $W e b$. Dan dalam memeriksa dokumen terdapat beberapa hal yang diperhatikan :

1. Akurasi atau ketepatan dokumen

2. Authority Web, dokumen yang telah diterbitkan dalam web

3. Objective information

\section{HASIL \& PEMBAHASAN}

3.1. Proses Bisnis Berjalan

Adapun prosedur sistem akademik pada SMP Islam Al-Fatah Jakarta yang pada saat ini masih berjalan adalah:

1. Prosedur Pengolahan Data Guru

Guru atau karyawan yang sudah diterima oleh pihak sekolah menyerahkan CuriculumVitae $(\mathrm{CV})$ dan mengisi form data guru serta data-data lain untuk kelengkapan data guru yang disertai dengan tanda tangan kontrak kerja, kemudian data guru yang sudah lengkap akan diarsipkan oleh staf bagian tata usaha dalam arsip guru. Dalam periode satu tahun sekali data guru yang ada pada arsip Guruakan dibuat laporan, laporan tersebut diberikan kepada Kepala Sekolah.

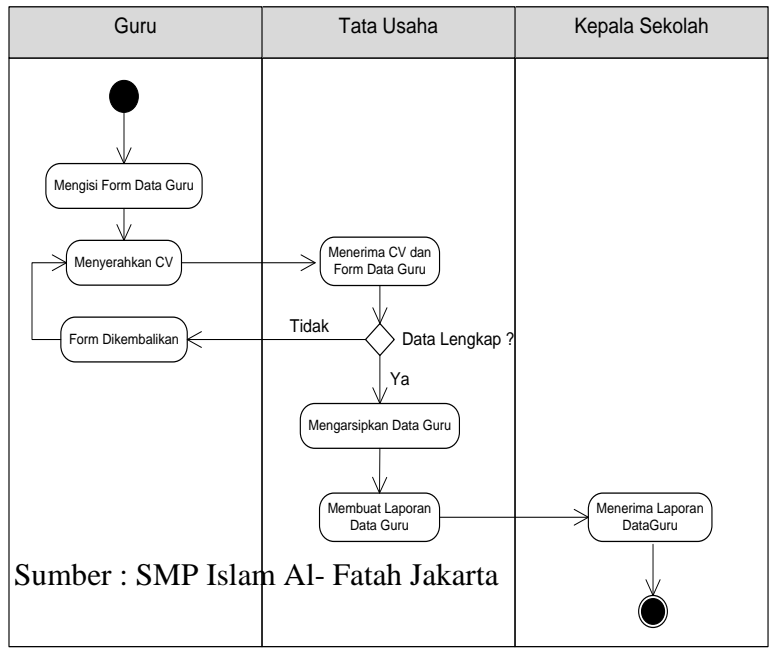

\section{Gambar 3. Activity Diagram Pengolahan Data Guru}

2. Prosedur Pengolahan Data Siswa

Siswa baru yang sudah diterima di SMP Islam Al-Fatah akan mengisi form data Siswa secara lengkap .Setelah data Siswa sudah lengkap diisi selanjutnya diberikan kepada staftata usaha untuk diolah dan diarsipkan menjadi arsip siswa.Data yang sudah diarsipkan selanjutnya dibuat laporan oleh staftata usaha untuk diberikan kepada Kepala Sekolah.

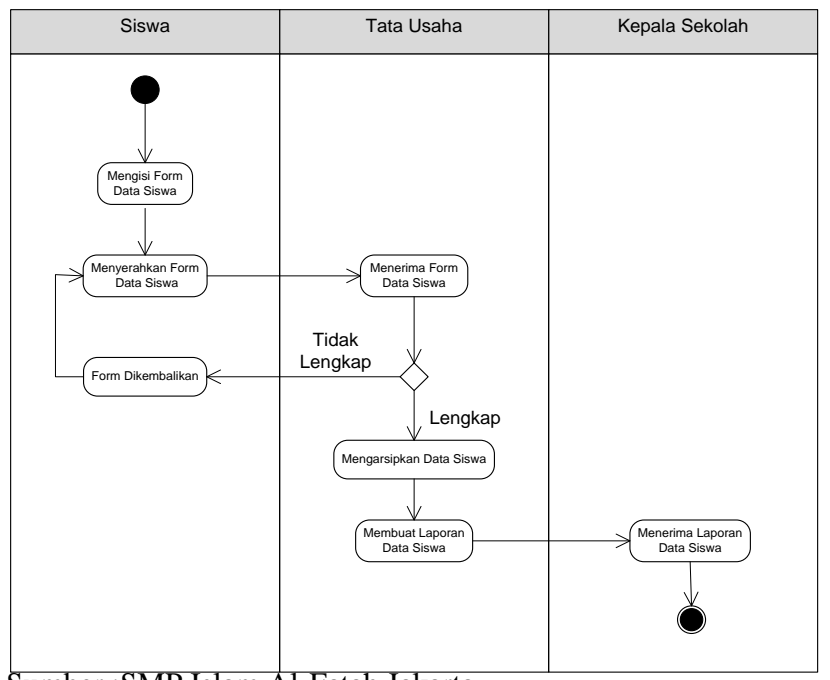

Sumber :SMP Islam Al-Fatah Jakarta

Gambar 4. ActivityDiagram Pengolahan Data Siswa

3. Prosedur Pengolahan Absen Guru

Guru mengisi daftar kehadiran melalui form absensi Guru yang diisi secara manual. Semua data absensi Guru setiap minggunya diambil oleh staftata usaha untuk dijadikan laporan kehadiran pamong.Rekap kehadiran selanjutnya di laporkan datanya kepada Kepala Sekolah.

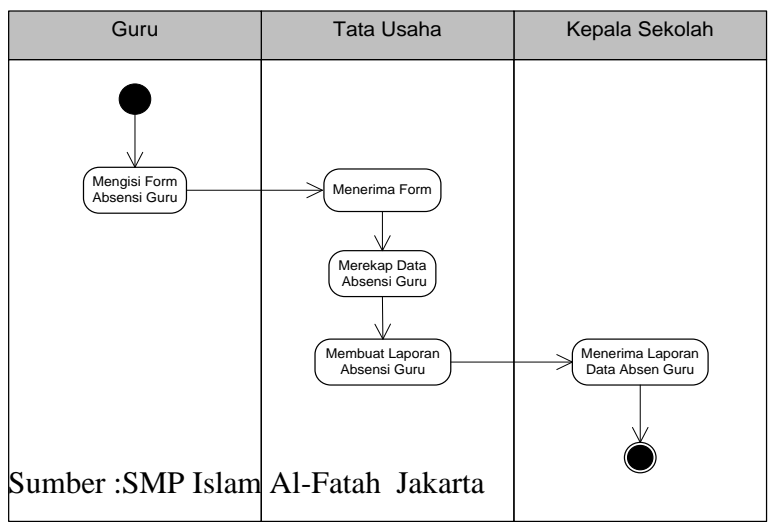




\section{Gambar 5. Activity Diagram Pengolahan absen Guru}

4. Prosedur Pengolahan Absen Siswa

Guru mencatat kehadiran siswa kedalam form absensi siswa, lalu diarsipkan. Dalam periode satu bulan arsip absen siswa diserahkan kepada wali kelas masing-masing yang kemudian dibuat laporan absen siswa yang ditujukan ke BK dan kepala sekolah.

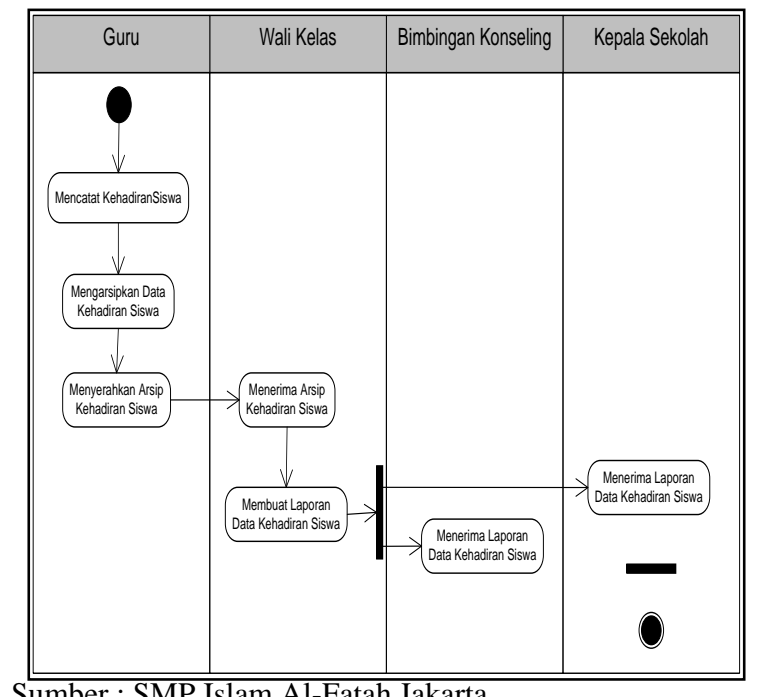

Gambar 6.

ActivityDiagram Pengolahan Absen Siswa

5. Prosedur Pengolahan Nilai Siswa

Nilai siswa yang sudah diproses oleh masingmasing guru dicatat ke dalam form nilai. Data nilai yang sudah direkap diserahkan kepada masing-masing wali kelas yang selanjutnya dilaporkan kepada kepala sekolah.

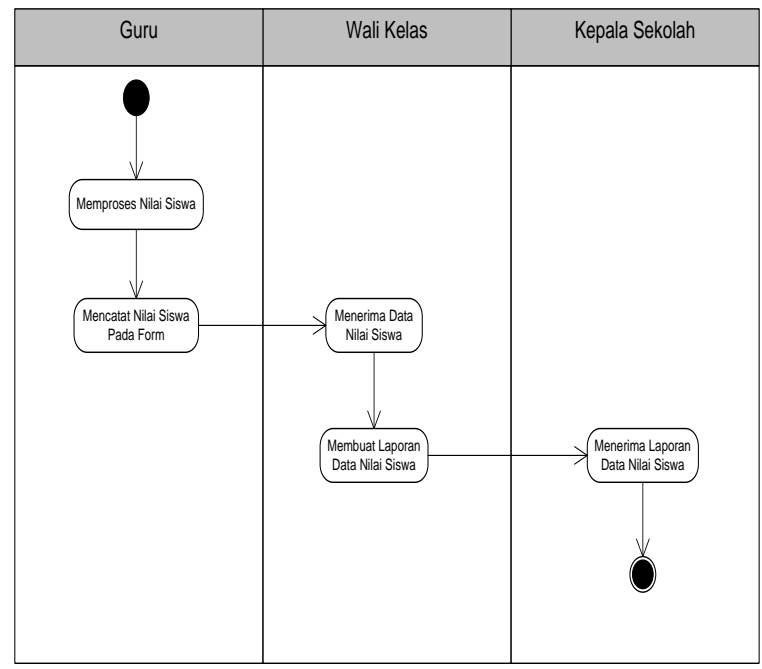

Sumber : SMP Islam Al-Fatah Jakarta

\section{Gambar 7.} ActivityDiagram Pengolahan Nilai Siswa

6. Use Case Diagram Halaman Siswa

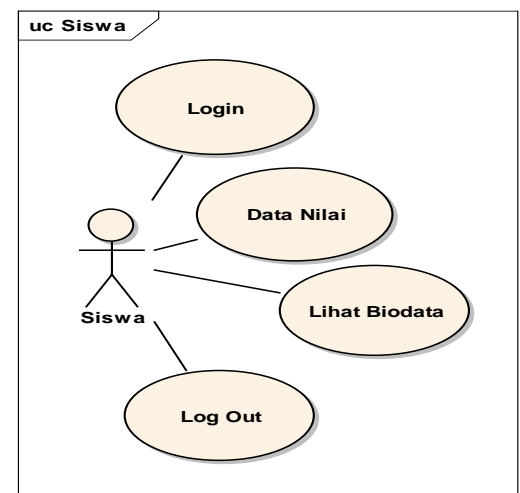

Sumber : SMP Islam Al-Fatah Jakarta

Gambar 8. Use Case Diagram

Sistem Informasi akademik Halaman Siswa

7. Use Case Diagram Halaman Guru

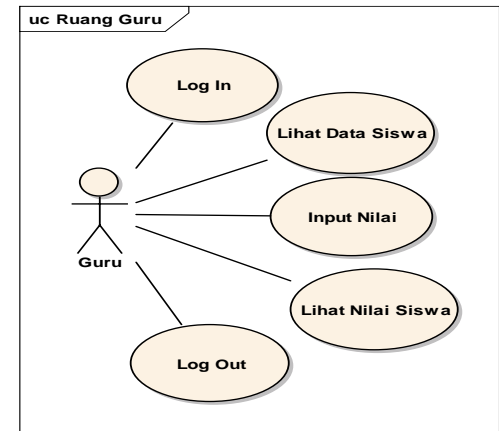

Sumber : SMP Islam Al-Fatah Jakarta

Gambar 9. Use Case Diagram Sistem Informasi akademik Halaman Guru

8. Use Case Diagram Halaman Admin

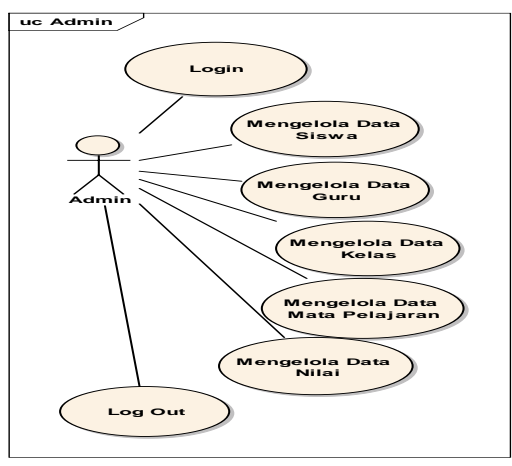

Sumber : SMP Islam Al-Fatah Jakarta

Gambar 10. Use Case Diagram 


\section{Sistem Informasi akademik Ruang Admin}

9. Use case diagram mengolah data Siswa uc Mengolah Data Siswa_revisi

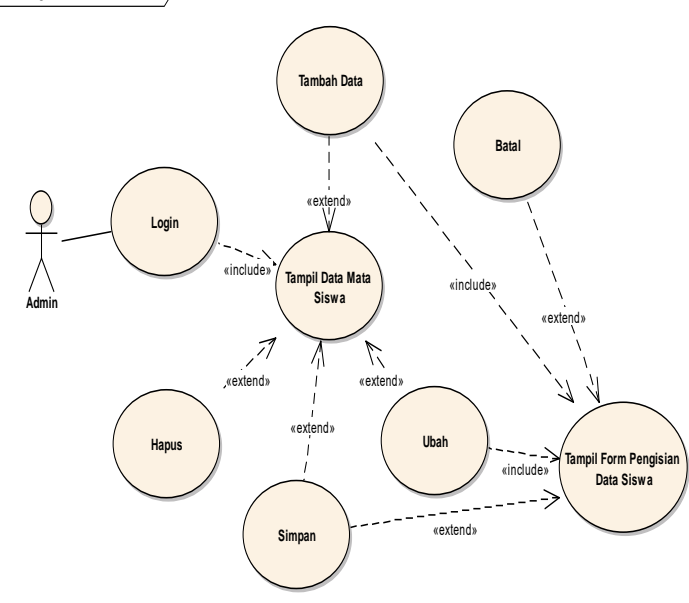

Sumber : SMP Islam Al-Fatah Jakarta

\section{Gambar 11. Detail Use Case Diagram mengelola data siswa}

10. Use case diagram mengolah data Guru

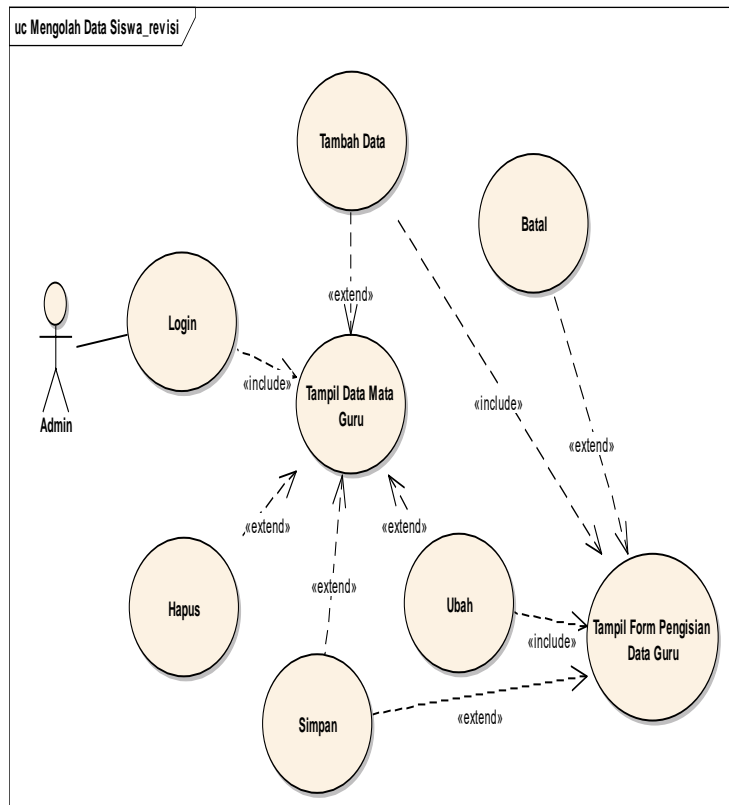

Sumber : SMP Islam Al-Fatah Jakarta

Gambar 12. Detail Use Case Diagram mengelola data Guru

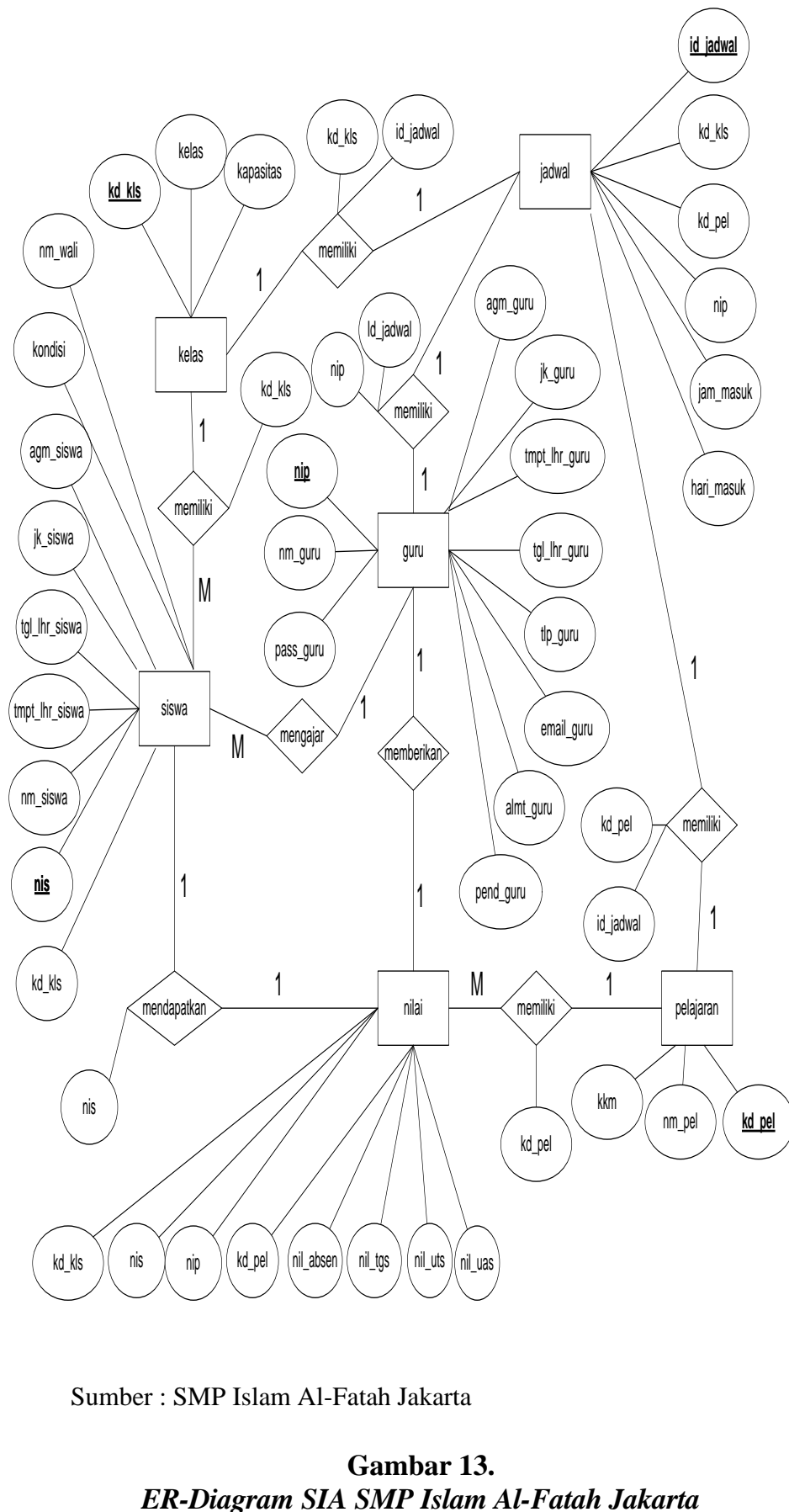

ER-Diagram SIA SMP Islam Al-Fatah Jakarta 


\section{Tampilan Halaman Home}

Halaman home adalah tampilan yang muncul di awal dari website yang pertama kali di lihat oleh pengunjung web.
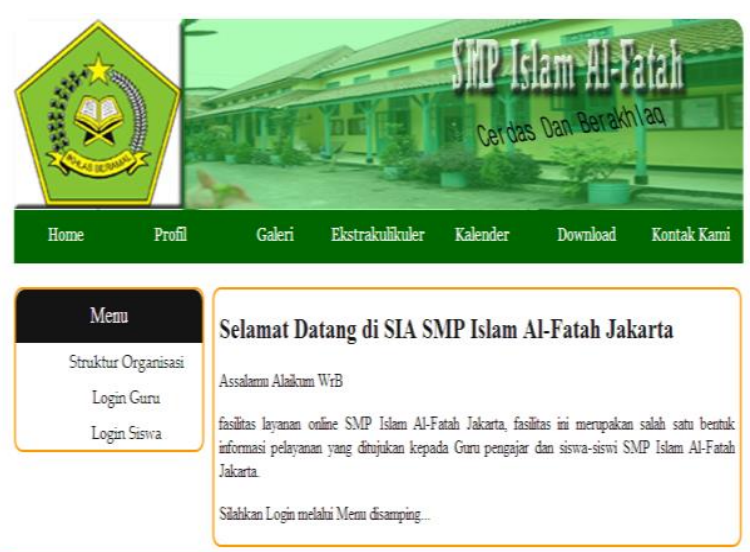

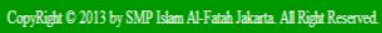

Sumber : SMP Islam Al-Fatah Jakarta

Gambar 14.

Tampilan Halaman Home

\section{Tampilan Halaman Profil}

Pada halaman ini, pengunjung dapat melihat profil dari SMP Islam Al-Fatah Jakarta.
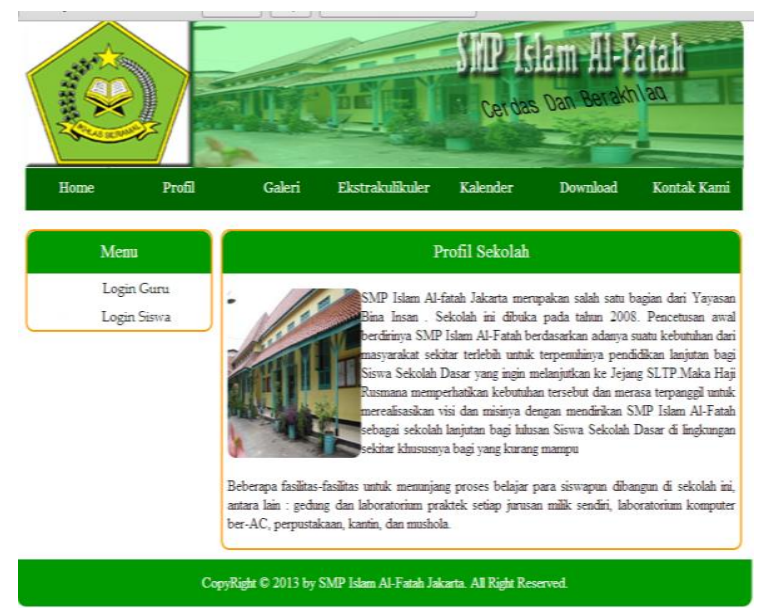

Sumber : SMP Islam Al-Fatah Jakarta

Gambar 15.

Tampilan Halaman Profil

\section{Tampilan Halaman Galeri Foto}

Pada halaman ini, pengunjung dapat melihat foto-foto kegiatan yang ada di SMP Islam Al-Fatah Jakarta.

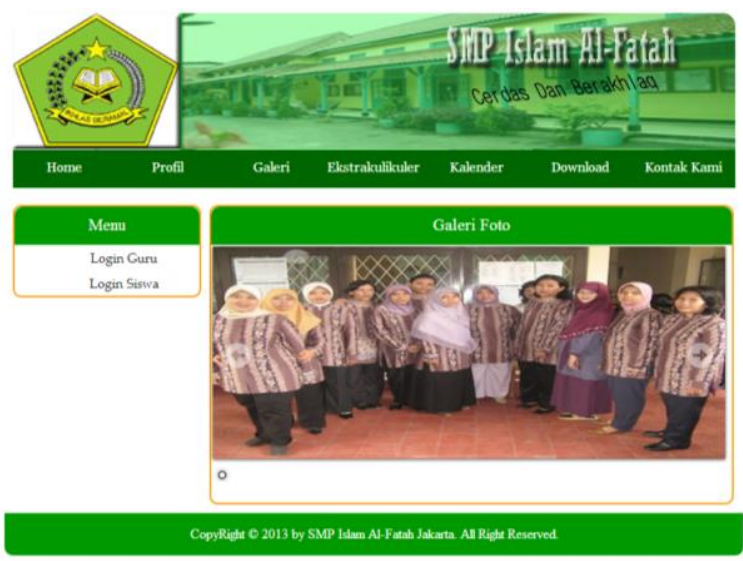

Sumber : SMP Islam Al-Fatah Jakarta

Gambar 16. Tampilan Halaman Galeri Foto

\section{Tampilan Halaman Kalender Akademik}

Pada halaman ini, pengunjung atau siswa dapat melihat kegiatan dan agenda akademik pada SMP Islam Al-Fatah Jakarta.

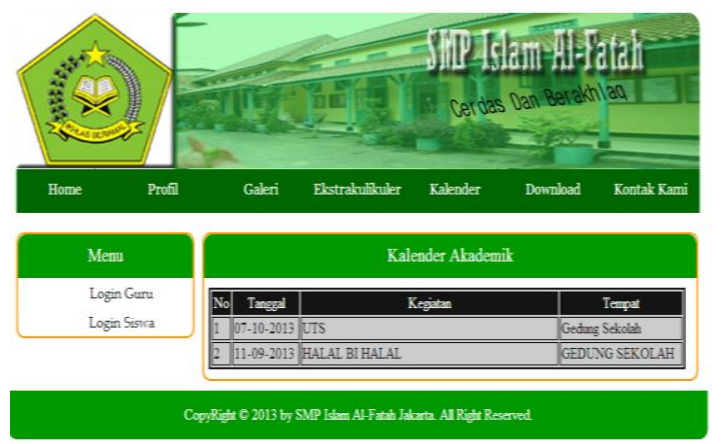

Sumber : SMP Islam Al-Fatah Jakarta

Gambar 17.

Tampilan Halaman Kalender Akademik 


\section{Tampilan Halaman Login Guru}

Pada halaman ini, Guru harus login terlebih dahulu untuk dapat masuk ke ruang Guru.

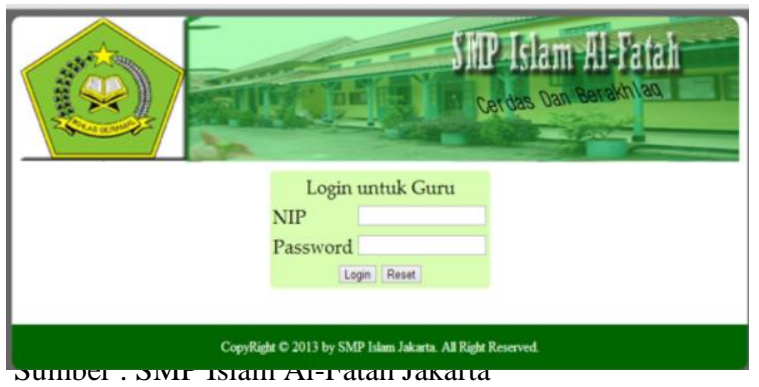

Gambar 18.

Tampilan Halaman Login Guru

Tampilan Halaman Login Siswa

Pada halaman ini, Siswa harus login terlebih dahulu untuk dapat masuk ke ruang siswa.

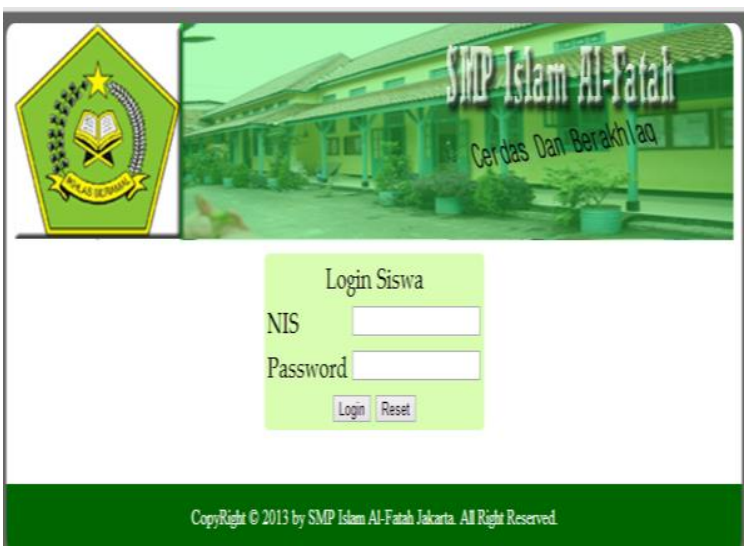

Sumber : SMP Islam Al-Fatah Jakarta

Gambar 19.

Tampilan Halaman Login Siswa

\section{KESIMPULAN \& SARAN}

\section{Kesimpulan}

Sistem informasi akademik yang dibangun ini ditujukkan kepada para ustad, Wali Murid dan siswa, untuk mendapatkan informasi akademik yang ada pada SMP Islam Al-Fatah Jakarta.

Informasi akademik yang diperoleh untuk siswa adalah berupa nilai-nilai akademik mereka, yaitu nilai absen, nilai tugas, nilai UTS, dan nilai UAS. Sedangkan pamong mempunyai hak akses untuk meng-upload nilai-nilai siswa.

Sistem informasi akademik sekolah berbasis web pada SMP Islam Al-Fatahl Bahri Jakarta dapat diakses dari mana saja dan kapan saja melalui jaringan internet sehingga relatif memudahkan siswa untuk melihat nilai-nilai akademik mereka kapan saja, tanpa harus datang ke sekolah.

Dengan adanya sebuah sistem informasi akademik ini diharapkan dapat meningkatkan eksistensi sekolah dan salah satu mempromosikan SMP Islam Al-fatah jakarta kepada masyarakat.

My $S q l$ sebagai server database untuk aplikasi PHP, memiliki kemudahan dalam integrasi keberbagai web cukup membantu dalam pengembangan sistem informasi akademik sekolah.

\section{Saran}

Sistem informasi akademik yang sudah dibangun ini harus mempunyai manfaat bagi penggunanya, yaitu Guru dan siswa. Untuk dapat menggunakan sistem ini, baiknya pihak pondok mengadakan pengenalan dan pelatihan untuk pamong menggunakan menu-menu ruang pamong, dan siswa bisa memanfaatkan fitur pada sistem, dan pihak sekolah mempunyai administrator sistem ini yang sudah terlatih sebelumnya untuk memanage sistem yang sudah ada.

Dari segi sistem yang telah ada, perlu adanya pengembangan dan fitur-fitur baru untuk menyempurnakan dan melengkapi sistem yang sudah ada untuk kedepannya.

Perlu diadakanya penelitian dan analisis berlanjut untuk mengembangkan sistem informasi akademik yang lebih baik dari sistem sebelumnya.

\section{REFRENSI}

Al Fatta, Hanif. 2007. Analisis dan Perancangan Sistem Informasi untuk Keunggulan Perusahaan dan Organisasi. Yogyakarta : ANDI.

Anhar. 2010. Panduan Menguasai PHP\&MYSQL Secara Otodidak. Jakarta : Media Kita.

Dengen, Nataniel dan Dyna Marisa Kh. 2009. Sistem Informasi Akademik SMP Negeri 4 Samarinda. Diambil dari : http://aptikom9.or.id/file/sistem-informasiakademik-berbasis-web.pdf (21 November 2012

Fathansyah. 2007. Buku Teks Komputer Basis Data. Bandung : Informatika.

HM, Jogiyanto. 2005. Sistem Teknologi Informasi. Yogyakarta : Andi Offset

Kadir, Abdul. 2009. Membuat Aplikasi Web dengan PHP + Database MySQL. Yogyakarta : Andi Offset.

Madcoms. 2008. Aplikasi Web Database Menggunakan Adobe Dreamweaver CS3 \& Pemrograman PHP + MySQL. Yogyakarta : Andi Offset. 
Mcleod, Reymond, George P Schell. 2008. Management Information System. Jakarta : Salemba Empat.

Munawar. 2005. Pemodelan Visual dengan UML. Yogyakarta : Graha Ilmu.

Sholiq. 2006. Pemodelan Sistem Informasi Berorientasi Objek dengan UML. Yogyakarta : Graha Ilmu.

Supriyanto, Aji. 2007. Pengantar Teknologi Informasi. Jakarta : Salemba Infotek.

Zulfadli, Rizal Munadi dan Yudha Nurdin. 2012. Sistem Informasi Prasyarat Mata Kuliah Berbasis Web. Diambil dari : http://elektro.unsyiah.ac.id/kitektro/wpcontent/uploads/2012/08/Kitektro_Vol01No 02Thn2012_Zulfadli_p70-77.pdf

November 2012) 